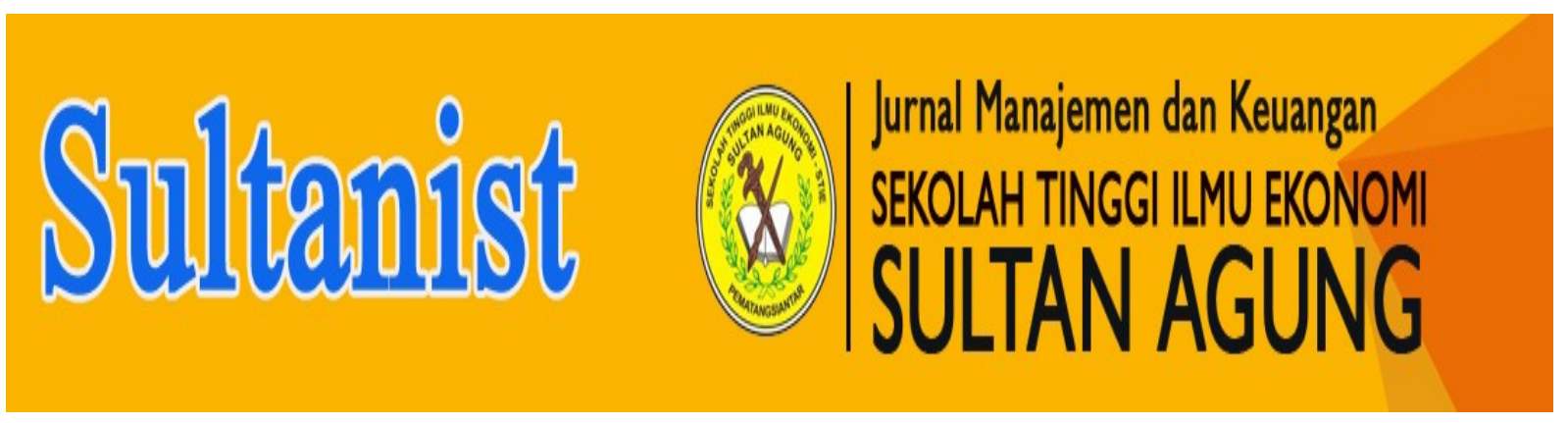

\title{
PENGARUH HARGA DAN KUALITAS PELAYANAN TERHADAP KEPUASAN PELANGGAN PADA BENGKEL ZUL KELUARGA JAYA
}

\author{
Oleh: \\ Zai Prayogie \\ S1 Manajemen \\ Darwin Lie, Marisi, Sudung
}

Abstraksi

Adapun rumusan masalah penelitian ini adalah bagaimana pengaruh harga dan kualitas pelayanan terhadap kepuasan pelanggan pada Bengkel Zul Keluarga Jaya. Metode penelitian yang digunakan dalam penulisan ini adalah penelitian kepustakaan dan penelitian lapangan. Populasinya adalah pegawai Bengkel Zul Keluarga Jaya berjumlah 30 pelanggan. Data yang digunakan adalah data dengan cara kualitatif dan data kuatitatif, dan teknik pengumpulan data dengan cara kuesioner, wawancara dan dokumentasi. Kemudian teknik analisa data menggunakan metode deskriptif kualitatif dan metode deskriptif kuantitatif.

Hasil analisa dari regresi linier berganda yaitu $\hat{Y}=3,629+0,386 X_{1}+0,299 X_{2}$ artinya terdapat pengaruh positif antara harga dan kualitas pelayanan terhadap kepuasan pelanggan. Kekuatan hubungan ketiga variabel adalah sangat kuat, yaitu $\mathrm{r}=0,826$. Dari koefisien determinasi dapat dijelaskan tinggi rendahnya kepuasan pelanggan $46,6 \%$, dan sisanya $53,4 \%$ dijelaskan oleh faktor lainnya yang yang tidak dibahas dalam penelitian ini. Dari hasil pengolahan dan perhitungan kuesioner, penulis mendapatkan kesimpulan bahwa harga dan kualitas pelayanan yang diterapkan Bengkel Zul Keluarga Jaya berpengaruh positif dan signifikan terhadap kepuasan pelanggan. Hal ini dibuktikan melalui uji hipotesis secara simultan, dimana hasil uji $\mathrm{F}_{\text {hitung }}(11,802)>\mathrm{F}_{\text {tabel }}(3,35)$ dengan taraf signifikansi $0,000<$ alpha 0,05 .

Kata Kunci: Harga, Kualitas pelayanan, Kepuasan Pelanggan

\section{Abstraction}

The formulation of this research problem is how the influence of price and quality of service to customer satisfaction at Bengkel Zul Keluarga Jaya. The research method used in this paper is literature research and field research. The population is employees of Bengkel Zul Keluarga Jaya amounting to 30 customers. The data used are data by qualitative and qualitative data, and data collection techniques by questionnaire, interview and documentation. Then the technique of data analysis using qualitative descriptive method and quantitative descriptive method.

Results of analysis of multiple linear regression is $\hat{Y}=3.629+0.386 X 1+0.299$ X2 means there is a positive influence between price and quality of service to customer satisfaction. The strength of the relationship of the three variables is very strong, ie $r=0.826$. From the coefficient of determination can be explained high low customer satisfaction $46.6 \%$, and the remaining $53.4 \%$ explained by other factors that are not discussed in this study. From the results of processing and calculation of the questionnaire, the authors to get the conclusion that the price and quality of service applied Bengkel Zul Keluarga Jaya positive and significant impact on customer satisfaction. This is proven by hypothesis testing simultaneously, where the test result Fhitung $(11,802)>$ Ftabel $(3,35)$ with significance level $0,000<$ alpha 0,05 .

Keywords: Price, Quality of service, Customer Satisfaction

\section{A. PENDAHULUAN}

\section{A. Latar Belakang Masalah}

Bengkel Zul Keluarga Jaya merupakan usaha dagang swasta yang bergerak pada bidang jasa bengkel mobil yang memberikan perbaikan (service mobil) dengan menggunakan media komunikasi antar sesama pelanggan. Saat ini Bengkel Zul Keluarga Jaya tidak hanya melayani jasa perbaikan saja, tetapi mulai menambah jasa seperti fiber glass (membuat modifikasi tambahan) yang ditujukan untuk bagian modifikasi sepeda motor serta mobil dan melakukan jual beli mobil bekas.

fenomena kepuasan pelanggan masih ada dalam kategori cukup puas, sehingga perlu dioptimalkan lagi. Pada kepuasan pelanggan terdapat tiga dimensi yaitu, kualitas produk, emosi, dan promosi. Untuk kepuasan pelanggan pada dimensi kualitas produk, belum optimal karena masih ada pelanggan yang menegeluh terhadap hasil perbaikan mobil. Dimensi emosi, pelanggan sudah cukup terikat secara berkelanjutan dari orangtua ke anaknya untuk melakukan perbaikan mobil di Bengkel Zul Keluarga Jaya, karena sudah beroperasi lebih dari 20 tahun. Dimensi promosi, kurangnya Bengkel Zul Keluarga Jaya memberikan promosi dalam bentuk Iklan di Radio, Surat Kabar. Bengkel Zul Keluarga Jaya hanya memberikan promosi melalui mulut kemulut, papan merek dan kartu nama.

Salah satu faktor yang mempengaruhi kepuasan pelanggan adalah harga. Adapun faktor harga diindikasikan dapat mempengaruhi kepuasan pelanggan. Strategi harga pada Bengkel Zul Keluarga Jaya dapat diukur dari dimensi keterjangkauan harga, diskon harga, cara 
pembayaran. Dimensi keterjangkauan harga relatif dapat bersaing dengan bengkel lain. Dimensi diskon harga diberikan pada pelanggan tetap sebesar $10 \%$ jika reparasi dengan biaya dengan biaya diatas $\mathrm{Rp}$. 5.000.000. Adapun dimensi cara pembayaran yang diterapkan Bengkel Zul Keluarga Jaya adalah pembayaran tunai ataupun non tunai (Auto Debet) berupa transaksi antar bank yang bertujuan agar pelanggan yang melakukan pembelian merasa aman.

Selain harga, kualitas pelayanan juga diindikasikan dapat mempengaruhi kepuasan pelanggan yang diberikan Bengkel Zul Keluarga Jaya diupayakan sesuai dengan harapan yang diinginkan oleh setiap pelanggan. Dimensi kualitas pelayanan terdiri dari bukti fisik (tangibles), kehandalan (reliability), ketanggapan (responsiveness), jaminan (assurance), empati (empathy). Pada dimensi bukti fisik (tangibles) yaitu ruangan disusun dengan perlengkapan-perlengkapan bengkel, assesoris dan sparepart secara rapi. Dimensi kehandalan (reliability) setiap pelanggan yang datang ke Bengkel Zul akan dilayani sebaik mungkin sesuai harapan pelanggan. Dimensi ketanggapan (responsiveness) yang diberikan Bengkel Zul seperti apabila ada pelanggan masuk ke bengkel maka akan langsung dilayani dan memberikan jawaban akan segala pertanyaan yang diberikan oleh pelanggan.

Dimensi jaminan (assurance) para karyawan Bengkel Zul sudah dibekali dengan pengetahuanpengetahuan akan mobil-mobil yang ada di bengkel sehingga jika ada pertanyaan dan keluhan akan mobil dari pelanggan maka akan ditanggapi langsung dengan sopan santun. Dimensi empati (empathy) memahami masalah pelanggan dan bertindak demi kepentingan pelanggan. Fenomena yang terjadi pada Bengkel Zul Keluarga Jaya yaitu empati ditinjau dari kurangnya berkomunikasi yang baik kepada pelanggan sehingga pelayanan yang diberikan kurang optimal dalam melayani pelanggan.

\section{B. Rumusan Masalah}

Berdasarkan uraian latar belakang dalam penelitian ini, adapun rumusan masalah sebagai berikut :

a. Bagaimana gambaran harga, kualitas pelayanan, dan kepuasan pelanggan pada bengkel $\mathrm{Zul}$ Keluarga Jaya.

b. Bagaimana pengaruh harga dan kualitas pelayanan terhadap kepuasan pelanggan pada Bengkel Zul Keluarga Jaya baik secara simultan maupun parsial.

\section{Tujuan Penelitian}

Adapun tujuan dari penelitian ini adalah sebagai berikut:

a. Untuk mengetahui gambaran harga, kualitas pelayanan, dan kepuasan pelanggan pada Bengkel Zul Keluarga Jaya.

b. Untuk mengetahui pengaruh harga dan kualitas pelayanan terhadap kepuasan pelanggan pada Bengkel Zul Keluarga Jaya baik secara simultan maupun parsial.

\section{Metode Penelitian}

Lokasi atau tempat penelitian ini dilakukan di Bengkel Zul Keluarga Jaya yang terletak di jalan Medan KM 4,5 Kelurahan Sumber Jaya Kecamatan Siantar Martoba Pematangsiantar. Pada penelitian ini yang menjadi populasi adalah pelanggab yang berada di lingkungan Bengkel Zul Keluarga Jaya sebanyak 30 orang yang sekaligus menjadi sampel penelitian.

Adapun Desain penelitian yang digunakan dalam penulisan skripsi ini adalah Penelitian Kepustakaan (Library Research) dan Penelitian Lapangan (Field Research). Teknik pengumpulan data yang dilakukan penulis dalam penelitian ini adalah berupa Kuesioner, Wawancara dan Dokumentasi. Adapun jenis data yang digunakan dalam penelitian ini adalah jenis data kualitatif dan data kuantitatif. Hasil data yang diperoleh dari lapangan akan dianalisis secara deskriptif baik bersifat kualitatif dan kuantitatif.

\section{B. LANDASAN TEORI}

\section{Manajemen}

Menurut Stoner dalam Handoko (2009:8), manajemen adalah suatu alur penggunaan sumber daya organisasi dengan melalui proses perencanaan, pengorganisasian, pengarahan, dan pengawasan untuk mencapai tujuan organisasi. Menurut Terry (2010:16), manajemen merupakan pemanfaatan sumber daya manusia dan sumber daya lainnya dengan proses tindakan-tindakan perencanaan, pengorganisasian, penggerakan dan pengendalian. Dari beberapa pengertian manajemen diatas, maka dapat disimpulkan bahwa manajemen adalah suatu kegiatan dalam menyusun pelaksanaan untuk mencapai suatu tujuan organisasi yang mengendalikan sumberdaya dan fasilitas kerja.

\section{Manajemen Pemasaran}

Pemasaran merupakan salah satu kegiatan pokok yang perlu dilakukan oleh perusahaan baik itu perusahaan barang atau jasa dalam upaya untuk mempertahankan kelangsungan hidup usahanya, untuk mendapatkan laba dan untuk berkembang.

Menurut Kotler dan Kevin (2009:5), manajemen pemasaran adalah keterampilan dan ilmu menentukan target pasar, menggapai, mempertahankan, serta menumbuhkan pelanggan dengan menciptakan, mengirim dan mengkomunikasikan nilai pelanggan yang unggul. Sedangkan menurut Kotler dan Gary (2008:10), manajemen pemasaran adalah sebagai seni dan ilmu memilih target pasar dan membangun hubungan yang menguntungkan dengan target pasar itu.

Berdasarkan defenisi diatas, penulis menyimpulkan bahwa manajemen pemasaran adalah proses mempertahankan pasar sasaran, menjaga pelanggan saat memenuhi harapannya sehingga dapat menciptakan tingkat kepuasan kepada pelanggan dan mempertahankan pertukaran yang menguntungkan dengan target pasar sasaran dengan maksud untuk mencapai tujuan utama perusahaan yaitu memperoleh laba. 


\section{Harga}

Dalam menetapkan harga, banyak faktor yang perlu dipertimbangkan secara teliti agar mendapat kepercayaan konsumen. Harga merupakan nilai yang diberikan kepada konsumen sebagai pengganti sebuah barang, oleh sebab itu harga harus sesuai dengan kualitas barang.

Menurut Kotler dan Garry (2008:439), harga adalah sejumlah dari nilai yang ditukar konsumen atas manfaat, karena memiliki atau menggunakan produk atau jasa tersebut. Sedangkan menurut Swastha (2002:241), harga merupakan jumlah uang (ditambah beberapa produk kalau mungkin) yang dibutuhkan untuk mendapat sejumlah kombinasi dari produk dan pelayannya. Menurut Krismono (2001:346), harga merupakan nilai tukar suatu produk yang dinyatakan dalam bentuk moneter.

Berdasarkan pendapat para ahli di atas, maka dapat disimpulkan bahwa harga merupakan nilai yang dibebankan pada suatu produk yang dapat ditukarkan dengan sejumlah uang.

Menurut Kotler dan Gary (2008:452), harga dapat diukur dengan beberapa dimensi yaitu:

Keterjangkauan Harga

1) Keterjangkauan harga merupakan harga sesungguhnya dari suatu produk yang tertulis di suatu produk yang harus dibayarkan oleh pelanggan. Maksudnya adalah pelanggan cenderung melihat harga akhir dan memutuskan akan menerima nilai yang baik seperti yang diharapkan.

2) Diskon Harga

Diskon merupakan penghargaan yang diberikan penjual kepada pembeli dalam bentuk pengurangan harga atas pembelian produk barang atau jasa tertentu. Adapun jenis diskon meliputi diskon kuantitas, diskon musiman, diskon tunai, dan diskon perdagangan.

3) Cara Pembayaran

Cara pembayaran sebagai prosedur dan mekanisme pembayaran suatu produk atau jasa sesuai ketentuan yang ada. Kemudahan dalam melakukan pembayaran dapat dijadikan sebagai salah satu pertimbangan bagi konsumen dalam melakukan keputusan pembelian.

Berdasarkan pendapat ahli di atas, dapat disimpulkan bahwa ada beberapa indikator dalam menentukan harga yakni keterjangkauan harga produk, potongan harga, cara pembayaran, biaya pemasaran, serta laba yang diharapkan konsumen dan perusahaan.

\section{Kualitas Pelayanan}

Jasa sering dipandang sebagai fenomena yang rumit. Kata jasa itu sendiri mempunyai banyak arti, dari mulai mutu pelayanan (service quality) sampai jasa sebagai suatu produk. Menurut Tjiptono (2008:7), pelayanan merupakan aktivitas, manfaat, atau kepuasan yang ditawarkan untuk dijual. Dalam dunia pemasaran, kepuasan konsumen menjadi tolak ukur dalam keberhasilan pelayanan.. Kemudian menurut Kotler dalam Tjiptono (2016:13), pelayanan adalah setiap tindakan atau perbuatan yang dapat ditawarkan oleh suatu pihak kepada pihak lain yang pada dasarnya bersifat intangible (tidak terwujud fisik) dan tidak menghasilkan kepemilikan sesuatu. Sedangkan menurut Nasution (2004:49), pelayan prima (Service Excellence) yakni suatu sikap atau cara karyawan dalam melayani pelanggan secara memuaskan.

Menurut Irawan (2004:58), dimensi kualitas pelayanan meliputi:

1) Bukti Fisik (Tangibles) $\backslash$

Kemampuan seseorang dalam menggunakan alat indra dalam melihat atau menilai suatu bentuk kualitas pelayanan.

2) Kehandalan (Reability)

Kemampuan dalam merefleksikan kecepatan dalam pelayanan sehingga dipersepsikan sebagai bagian yang krusial bagi pelanggan dalam berbagai industri jasa.

3) Ketanggapan (Revonsiveness)

Harapan pelanggan terhadap kecepatan pelayanan hampir dapat dipastikan akan berubah dengan cenderungan naik dari waktu ke waktu.

4) Jaminan (Assurance)

Yaitu dimensi kualitas yang berhubungan dengan kemampuan perusahaan dalam menanamkan dan mengelola rasa percaya dan keyakinan kepada para pelanggannya

5) Empati (Emphaty)

Yaitu bahwa perusahaan memahami masalah para pelanggannya dan bertindak demi kepentingan pelanggan, serta memberikan perhatian personal kepada para pelanggan.

Berdasarkan dimensi-dimensi yang diuraikan diatas, maka dapat kita simpulkan dimensi kualitas pelayanan terdiri dari reability, assurance, tangibles, emphaty, responsiveness. Dimensi kualitas pelayanan juga memberikan nilai tambah dalam hal mendorong keinginan pelanggan untuk membeli barang atau menggunakan jasa kita.

\section{Kepuasan Pelanggan}

Kepuasan pelanggan sangat dibutuhkan pada perusahaan dimana keinginan, harapan, dan kebutuhan pelanggan terpenuhi. Menurut Day dalam Tjiptono (2008:24), kepuasan pelanggan adalah respon pelanggan terhadap evaluasi ketidak sesuaian yang dirasakan antara harapan sebelumnya dan kinerja aktual produk yang dirasakan setelah pemakaiannya. Menurut Kotler (2007:177), kepuasan pelanggan adalah hasil produk yang dipikirkan oleh seorang pelanggan sebagai bentuk ungkapan senang atau kecewa setelah membandingkan kinerja atau hasil suatu produk yang sesuai harapannya. Sedangkan menurut Gerson (2002:112), kepuasan pelanggan adalah persepsi bahwa harapan telah terpenuhi atau terlampaui dan tetap lanjut berhubungan dengan perusahaan, dan sebaliknya jika pelanggan tidak puas, dia akan menghentikan bisnisnya dengan perusahaan.

Berdasarkan defenisi diatas, dapat ditarik kesimpulan bahwa kepuasan pelanggan adalah respon yang terpenuhi terhadap yang ditawarkan oleh perusahaan untuk memenuhi segala kebutuhan 
pelanggan yang dirasakan antara harapan dan kenyataan setelah pemakaian.

Menurut Lupiyoadi dan Hamdani (2001:158), menyatakan bahwa ada lima dimensi kepuasan pelanggan, antara lain:

1) Kualitas produk

Yaitu pelanggan akan merasa puas bila hasil mereka menunjukan bahwa produk yang mereka gunakan berkualitas.

2) Emosi

Yaitu

Kepuasan yang diperoleh bukan karena kualitas dari produk tetapi sosial atau self esteem yang membuat pelanggan merasa puas terhadap merek tertentu.

3) Promosi

Yaitu dasar penelitian promosi mengenai informasi produk dan jasa perusahaan dalam usaha mengkomunikasikan manfaat produk dan jasa pada konsumen sasaran. Penelitian dalam hal ini meliputi iklan produk dan jasa, diskon barang dan pemberian hadiah.

Berdasarkan penjelasan diatas, maka penulis dapat menyimpulkan bahwa dimensi kepuasan pelanggan dapat diukur melalui kualitas produk, kualitas pelayanan, emosi, harga dan biaya.

\section{Pengaruh Harga dan Kualitas Pelayanan Terhadap Kepuasan Pelanggan}

Pelanggan adalah orang yang menerima hasil pekerjaan atau produksi suatu perusahaan, maka hanya pelangganlah yang dapat menentukan kualitasnya seperti apa dan hanya pelanggan yang dapat menyampaikan bentuk kebutuhan mereka. Dalam membeli barang maupun jasa pelanggan pasti mempertimbangkan harga yang akan dibelinya dan kualitas pelayanan yang didapatkannya. Oleh sebab itu, perusahaan harus cermat dalam menetapkan harga dari suatu produk atau jasa dan memberikan kualitas pelayanan yang terbaik sesuai dengan harapan pelanggan.

Menurut Kotler dan Kevin (2009:76), harga sering ditetapkan untuk memuaskan permintaan dan mencerminkan premi yang bersedia dibayarkan konsumen untuk sebuah produk maupun jasa. Mayoritas seorang pembeli mempertimbangkan harga sebagai indikator kualitas penetapan harga pencitraan sangat efektif untuk produk sensitif ego. Selain itu, konsumen juga selalu memeriksa informasi harga dan nama merek berbeda ketika membuat penilaian pada ukuran kualitas, kemudahan penggunaan, kegunaan, kinerja, ketahanan dan status.

Sedangkan menurut Zeithaml dan Bitner dalam Lupiyoadi dan Hamdani (2006:192), faktor utama penentu kepuasan pelanggan adalah persepsi pelanggan terhadap kualitas pelayanan. Dengan adanya kemampuan penyedia pelayanan untuk menyampaikan layanan melebihi tingkat kepentingan pelanggan maka dapat menimbulkan tingkat kepercayaan pelanggan terhadap penyedia layanan. Selain hal tersebut, penyedia layanan harus mampu berinteraksi lebih baik lagi dengan para pelanggannya, yang pada akhirnya akan menciptakan dan meningkatkan kepuasan pelanggan.

Dari beberapa pendapat para ahli, maka penulis menyimpulkan bahwa harga yang terjangkau dan kualitas pelayanan yang terbaik, maka pelanggan akan merasa puas atas pelayanan yang mereka terima.

\section{PEMBAHASAN}

\section{Analisa}

\section{a. Deskriptif Kualitatif}

Analisis deskriptif dimaksudkan untuk mendapat gambaran atau tanggapan dari pelanggan mengenai pengaruh disiplin kerja dan komunikasi terhadap kualitas pelayanan pada Bengkel Zul Keluarga Jaya. Sesudah pengujian data, maka langkah selanjutnya peneliti melakukan pengkajian analisa kualitatif sebagai gambaran fenomena dari variabel penelitian pada sekarang ini.

Adapun penetapan kriteria nilai rata-rata jawaban dari responden tersebut dimasukkan ke dalam kelas-kelas interval menggunakan rumus sebagai berikut:

$$
\begin{aligned}
& \text { Interval kelas }=\frac{\text { Nilai Tertinggi }- \text { Nilai Terend ah }}{\text { (jumlah kelas interval) }} \\
& =\frac{5-1}{5} \\
& =\frac{4}{5}
\end{aligned}
$$$$
=0,8
$$

Dari rumus di atas, diperoleh nilai interval kelas $=$ 0,8 , sehingga berlaku ketentuan kategori dengan hasil sebagai berikut:

Tabel 1

Nilai Interval dan Kategori Jawaban Responden

\begin{tabular}{|c|c|}
\hline Nilai Interval & Kategori Pertanyaan \\
\hline $4,21-5,00$ & Sangat Baik \\
\hline $3,41-4,20$ & Baik \\
\hline $2,61-3,40$ & Cukup Baik \\
\hline $1,81-2,60$ & Tidak Baik \\
\hline $1,00-1,80$ & Sangat Tidak Baik \\
\hline
\end{tabular}

Sumber: hasil pengolahan data (2017)

\section{Gambaran Harga Pada Bengkel Zul Keluarga Jaya}

Harga dianggap sebagai salah satu faktor yang menentukan bagi suatu perusahaan, tetapi stretegi harga bukanlah merupakan satu-satunya cara untuk mengatasi berbagai persoalan dalam perusahaan, namun setiap perusahaan hendaknya mempertimbangkan secara matang setiap keputusan dalam masalah harga.

Strategi harga pada Bengkel Zul Keluarga Jaya dapat diukur dari dimensi keterjangkauan harga, potongan harga, cara pembayaran. Dimensi keterjangkauan harga relatif dapat bersaing dengan bengkel lain. Dimensi potongan harga harga diberikan pada pelanggan tetap sebesar $10 \%$ jika reparasi dengan biaya dengan biaya diatas Rp. 5.000.000. Adapun dimensi cara pembayaran yang 
diterapkan Bengkel Zul Keluarga Jaya adalah pembayaran tunai ataupun non tunai (Auto Debet) berupa transaksi antar bank yang bertujuan agar pelanggan yang melakukan pembelian merasa aman.

\section{Gambaran Kualitas Pelayanan pada Bengkel Zul Keluarga Jaya}

Kualitas Pelayanan merupakan pelayanan merupakan aktivitas, manfaat, atau kepuasan yang ditawarkan untuk dijual. Dalam dunia pemasaran, kepuasan konsumen menjadi tolak ukur dalam keberhasilan pelayanan. Pelayanan merupakan perilaku produsen dalam rangka memenuhi kebutuhan dan keinginan konsumen demi tercapainya kepuasan pada konsumen itu sendiri.

kualitas pelayanan juga diindikasikan dapat mempengaruhi kepuasan pelanggan yang diberikan Bengkel Zul Keluarga Jaya diupayakan sesuai dengan harapan yang diinginkan oleh setiap pelanggan. Dimensi kualitas pelayanan terdiri dari bukti fisik (tangibles), kehandalan (reliability), ketanggapan (responsiveness), jaminan (assurance), empati (empathy). Pada dimensi bukti fisik (tangibles) yaitu ruangan disusun dengan perlengkapan-perlengkapan bengkel, assesoris dan sparepart secara rapi. Dimensi kehandalan (reliability) setiap pelanggan yang datang ke Bengkel Zul akan dilayani sebaik mungkin sesuai harapan pelanggan. Dimensi ketanggapan (responsiveness) yang diberikan Bengkel Zul seperti apabila ada pelanggan masuk ke bengkel maka akan langsung dilayani dan memberikan jawaban akan segala pertanyaan yang diberikan oleh pelanggan.

\section{Gambaran Kepuasan Pelanggan pada Bengkel Zul Keluarga Jaya}

Kepuasan pelanggan adalah perasaan senang atau kecewa pelanggan yang muncul setelah membandingkan kinerja atau hasil produk yang dipikirkan terhadap kinerja atau hasil yang diharapkan.

Pada kepuasan pelanggan terdapat tiga dimensi yaitu, kualitas produk, emosi, dan promosi. Untuk kepuasan pelanggan pada dimensi kualitas produk, belum optimal karena masih ada pelanggan yang menegeluh terhadap hasil perbaikan mobil. Dimensi emosi, pelanggan sudah cukup terikat secara berkelanjutan dari orangtua ke anaknya untuk melakukan perbaikan mobil di Bengkel Zul Keluarga Jaya, karena sudah beroperasi lebih dari 20 tahun. Dimensi promosi, kurangnya Bengkel Zul Keluarga Jaya memberikan promosi dalam bentuk Iklan di Radio, Surat Kabar. Bengkel Zul Keluarga Jaya hanya memberikan promosi melalui mulut kemulut, papan merek dan kartu nama.

\section{b. Deskriptif Kuantitatif}

\section{1) Analisa Regresi Linear Berganda}

Penelitian ini memiliki tujuan untuk menganalisis pengaruh harga dan kualitas pelayanan terhadap kepuasan pelanggan. Analisis regresi linier berganda digunakan untuk mengetahui pengaruh variabel bebas $(\mathrm{X})$ dan variabel terikat $(\mathrm{Y})$, dimana
$\mathrm{X}_{1}$ adalah harga, $\mathrm{X}_{2}$ adalah kualitas pelayanan, dan $\mathrm{Y}$ adalah kepuasan pelanggan. Maka dilakukan perhitungan menggunakan program aplikasi SPSS untuk memperoleh nilai $a$ dan $b$ dengan notasi sebagai berikut: $\hat{Y}=b_{0}+b_{1} X_{1}+b_{2} X_{2}$.

Tabel 17

Analisis Regresi Linier Berganda

\begin{tabular}{|l|r|r|r|}
\hline \multirow{2}{*}{ Model } & \multicolumn{2}{|c|}{$\begin{array}{c}\text { Unstandardized } \\
\text { Coefficients }\end{array}$} & $\begin{array}{c}\text { Standardized } \\
\text { Coefficients }\end{array}$ \\
\cline { 2 - 4 } & \multicolumn{1}{|c|}{$\boldsymbol{B}$} & Std. Error & \multicolumn{1}{c|}{ Beta } \\
\hline 1 (Constant) & $\mathbf{3 . 6 2 9}$ & 7.020 & \\
Harga & $\mathbf{. 3 8 6}$ & .179 & .346 \\
Kualitas pelayanan & $\mathbf{. 2 9 9}$ & .97 & .470 \\
\hline
\end{tabular}

a. Dependent Variabel: Kepuasan Pelanggan

Sumber: hasil pengolahan kuesioner menggunakan spss versi 21 (2017)

Berdasarkan hasil penelitian tabel 17, maka dapat disusun persamaan regresi sebagai berikut: $\hat{\mathrm{Y}}=3,629+0,386 \mathrm{X}_{1}+0,299 \mathrm{X}_{2}$, artinya terdapat pengaruh yang positif antara harga $\left(\mathrm{X}_{1}\right)$ dan kualitas pelayanan $\left(\mathrm{X}_{2}\right)$ terhadap kepuasan pelanggan $(\mathrm{Y})$ pada Bengkel Zul Keluarga Jaya.

\section{2) Korelasi dan Koefisien Determinasi}

Untuk menghitung kekuatan hubungan disiplin kerja, komunikasi dan kinerja pegawai, dilakukan melalui analisis korelasi dan koefisien determinasi dengan rumus sebagai berikut:

Tabel 18

Korelasi dan Koefisien Determinasi

\begin{tabular}{|r|r|r|r|r|}
\hline Model & $\mathbf{R}$ & $\boldsymbol{R}$ Square & $\begin{array}{c}\text { Adjusted } R \\
\text { Square }\end{array}$ & $\begin{array}{c}\text { Std. Error of the } \\
\text { Estimate }\end{array}$ \\
\hline 1 & $\mathbf{. 6 8 3}$ & $\mathbf{. 4 6 6}$ & .427 & 3.869 \\
\hline
\end{tabular}

a. Predictors: (Constant), Harga, Kualitas Pelayanan

b. Dependent Variabel: Kepuasan Pelanggan

Sumber: hasil pengolahan kuesioner menggunakan spss versi 21 (2017)

Berdasarkan hasil penelitian pada tabel 18 , diperoleh $\mathrm{r}$ sebesar 0,683 , yang artinya terdapat hubungan yang kuat dan positif antara harga, kualitas pelayanan dan kepuasan pelanggan di Bengkel Zul Keluarga Jaya. Sesuai tabel selanjutnya diperoleh koefisien determinasi $(\mathrm{R})=0,466$ artinya tinggi rendahnya kepuasan pelanggan (Y) di Bengkel Zul Keluarga Jaya sebesar $46,60 \%$ dapat dijelaskan oleh harga $\left(\mathrm{X}_{1}\right)$ dan kualitas pelayanan $\left(\mathrm{X}_{2}\right)$, sedangkan sisanya $53,4 \%$ dipengaruhi oleh faktor lain yaitu, citra merek, pelayanan, harga, promosi dan faktor lain yang tidak dibahas dalam penelitian ini.

\section{3) Uji Hipotesis}

a) Uji Simultan (Uji F)

Uji $F$ digunakan untuk mengetahui apakah variabel bebas (harga dan kualitas pelayanan) berpengaruh terhadap variabel terikat (kepuasan pelanggan) secara bersama-sama atau simultan. Yaitu dilakukan untuk menentukan diterima atau 
ditolaknya hipotesis. Jika tingkat signifikan dibawah $5 \%$ atau $\mathrm{F}_{\text {hitung }}>\mathrm{F}_{\text {tabel maka }} \mathrm{H}_{0}$ ditolak.

Tabel 19

\begin{tabular}{|c|c|c|c|c|c|}
\hline \multicolumn{6}{|c|}{ Perkiraan Nilai Fhitung } \\
\hline Model & $\begin{array}{l}\text { Sum of } \\
\text { Squares }\end{array}$ & df & $\begin{array}{l}\text { Mean } \\
\text { Square }\end{array}$ & $\mathbf{F}$ & Sig. \\
\hline Regression & 353,309 & 2 & 176,654 & 11,802 & $.000^{b}$ \\
\hline Residual & 404,158 & 27 & 14,969 & & \\
\hline Total & 757,467 & 29 & & & \\
\hline
\end{tabular}

a. Dependent Variabel: Kepuasan Pelanggan

b. Predictors: (Constant), Harga, Kualitas Pelayanan

Sumber: hasil pengolahan kuesioner menggunakan spss versi 21 (2017)

Berdasarkan table 20 di atas, diperoleh nilai $F_{\text {hitung }}$ sebesar $11,802>F_{\text {tabel }(0,05 ; 2 ; 30)}$ sebesar 3,35 atau dengan taraf signifikansi $0,000<\alpha=0,05$ maka $\mathrm{H}_{0}$ ditolak, artinya harga dan kualitas pelayanan berpengaruh positif dan signifikan terhadap kepuasan pelanggan di Bengkel Zul Keluarga Jaya.

b) Uji Parsial (Uji t)

Untuk menghasilkan suatu kesimpulan yang valid, maka harus dilakukan uji hipotesis. Pengujian ini dilakukan untuk menentukan diterima atau ditolaknya hipotesis, pengujian hipotesis dilakukan untuk mengetahui apakah variabel disiplin kerja dan komunikasi yang diuji berpengaruh terhadap kinerja pegawai. Jika tingkat signifikansi dibawah 5\% atau

$t_{\text {hitung }}>\mathrm{t}_{\text {tabel maka }} \mathrm{H}_{0}$ ditolak.

Tabel 20

\begin{tabular}{|l|r|r|}
\hline \multicolumn{3}{|c|}{ Perkiraan Nilai thitung } \\
\hline \multicolumn{1}{|c|}{ Model } & T & Sig. \\
\hline 1 (Constant) &, 517 &, 609 \\
& & \\
Harga & $\mathbf{2 , 2 6 7}$ & $\mathbf{, 0 3 2}$ \\
Kualitas Pelayanan & $\mathbf{3 , 0 7 8}$ & $\mathbf{, 0 0 5}$ \\
\hline
\end{tabular}

a. Dependent Variabel: Kepuasan Pelanggan

Sumber: hasil pengolahan kuesioner menggunakan spss versi 21 (2017)

Dari tabel 20 di atas, dapat dilihat nilai thitung pada variabel Harga $\left(\mathrm{X}_{1}\right)$ sebesar 2,267 $>$ dari $t_{\text {tabel }}$ dengan $\mathrm{df}=\mathrm{n}-\mathrm{k}-1 \quad(30-2-1=27)$ sebesar 2,05183 atau taraf signifikan $0,032<\alpha 0,05$ maka $\mathrm{H}_{0}$ ditolak, artinya harga berpengaruh positif dan signifikan terhadap kepuasan pelanggan di Bengkel Zul Keluarga Jaya. Kemudian nilai $\mathrm{t}_{\text {hitung }}$ pada variabel $\mathrm{X}_{2}$ kualitas pelayanan sebesar 3,078 $>$ dari $t_{\text {tabel }}$ dengan $\mathrm{df}=\mathrm{n}-\mathrm{k}-1,(30-2-1=27)$ sebesar 2,05183 atau taraf signifikan $0,005<\alpha 0,05$, maka $\mathrm{H}_{0}$ ditolak, artinya kualitas pelayanan berpengaruh positif dan signifikan terhadap kepuasan pelanggan di Bengkel Zul Keluarga Jaya.

\section{Evaluasi}

\section{a. Harga Pada Bengkel Zul Keluarga Jaya}

Harga dianggap sebagai salah satu faktor yang menentukan bagi suatu perusahaan, tetapi stretegi harga bukanlah merupakan satu-satunya cara untuk mengatasi berbagai persoalan dalam perusahaan, namun setiap perusahaan hendaknya mempertimbangkan secara matang setiap keputusan dalam masalah harga

Harga di Bengkel Zul Keluarga Jaya dapat dikatakan baik, hal ini dapat dilihat dari kuesioner yang dibagikan kepada reponden yang secara keseluruhan diperoleh nilai rata-rata sebesar 3,94 dengan kriteria jawaban baik. Namun ada beberapa aspek yang masih di bawah rata-rata dari indiktorindikator lain, yang pertama yaitu pada indikator penentuan harga diperoleh nilai rata-rata sebesar 3,23 dengan kriteria jawaban cukup baik. Untuk mengatasi hal ini Bengkel Zul seharusnya tidak membuat harga terlalu tinggi.

Untuk indikator diskon diperoleh nilai ratarata sebesar 3,30 dengan kriteria jawaban cukup baik. Cara mengatasinya bengkel zul memberikan potongan harga kepada pelanggan sebanyak $10 \%$ jika pelanggan belanja di atas 5 juta ke atas. Untuk indikator pemberian bonus diperoleh nilai rata-rata sebesar 3,93 dengan kriteria jawaban baik. Cara meningkatkannya bengkel zul memberi souvenir kepada pelanggan yang selalu datang ke bengkel zul.

Dari hasil evaluasi di atas dapat diambil kesimpulan jika semua hal-hal di atas sudah dinyatakan dengan baik. Walaupun sudah dinyatakan baik, Bengkel Zul Keluarga Jaya perlu memperbaiki kekurangan-kekurangannya.

\section{b. Kualitas Pelayanan pada Bengkel Zul Keluarga Jaya}

Kualitas Pelayanan merupakan pelayanan merupakan aktivitas, manfaat, atau kepuasan yang ditawarkan untuk dijual. Dalam dunia pemasaran, kepuasan konsumen menjadi tolak ukur dalam keberhasilan pelayanan. Pelayanan merupakan perilaku produsen dalam rangka memenuhi kebutuhan dan keinginan konsumen demi tercapainya kepuasan pada konsumen itu sendiri.

Kualitas Pelayanan terhadap Bengkel Zul Keluarga Jaya dapat dikatakan baik, hal ini dapat dilihat dari hasil kuesioner yang diperoleh nilai ratarata sebesar 3,74 dengan kriteria jawaban baik. Namun dari nilai rata-rata tersebut masih ada beberapa yang memiliki dibawah total nilai rata-rata, yang pertama dengan indikator memiliki pengetahuan yang cukup tentang produk diperoleh nilai rata-rata sebesar 3,23 dengan kriteria jawaban cukup baik. Cara mengatasinya atasan harus memberikan pelatihan kepada karyawan agar memiliki pengetahuan lebih banyak lagi tentang produk tersebut.

Untuk indikator sikap tanggap yang di tunjukan pada pelanggan nilai rata-rata sebesar 3,37 dengan kriteria jawaban cukup baik. Cara meningkatkannya karyawan harus lebih cepat menangkap keluhan-keluhan pada pelanggan. Untuk indikator konsumen merasa aman saat berbelanja 
diperoleh nilai rata-rata sebesar 3,67 dengan kriteria jawaban baik. Cara meningkatkannya bengkel zul harus nambah keamanan pada saat pelanggan berbelanja seperti saat melakukan transaksi pembayaran.

Dari evaluasi di atas dapat diambil kesimpulan bahwa kualitas pelayanan dinyatakan baik, dengan memperbaiki kekurangan dari bengkel zul agar konsumen terus datang sehingga dapat meningkatkan penjualan-penjulan produk di Bengkel Zul Keluarga Jaya.

\section{c. Kepuasan Pelanggan pada Bengkel Zul Keluarga Jaya}

Kepuasan pelanggan adalah perasaan senang atau kecewa pelanggan yang muncul setelah membandingkan kinerja atau hasil produk yang dipikirkan terhadap kinerja atau hasil yang diharapkan. Proses kepuasan pelanggan ada lima dimensi, antara lain. Kualitas produk, yaitu pelanggan akan merasa puas bila hasil mereka menunjukan bahwa produk yang mereka gunakan berkualitas. Emosi, yaitu pelanggan akan merasa bangga dan mendapatkan keyakinan bahwa orang lain akan kagum terhadap dia bila menggunakan produk dengan merek tertentu yang cenderung mempunyai tingkat kepuasan yang lebih tinggi.

Hasil pengujian secara umum terhadap variabel kepuasan pelanggan diperoleh nilai rata-rata sebesar 3,75 dengan kriteria jawaban puas. Namun dari nilai rata-rata tersebut ada beberapa indikator yang masih dibawah rata-rata. Pada Indikator daya tahan produk diperoleh nilai rata-rata sebesar 3,23 dengan kriteria jawaban cukup puas. Cara meningkatkannya adalah bengkel zul harus lebih meningkatkan lagi kualitas produk.

Indikator kesesuaian promosi diperoleh nila rata-rata sebesar 3,37 dengan kriteria jawaban cukup puas. Cara meningkatkannya adalah informasi yang di berikan harus lebih jelas dan sesuai dengan apa yang ditawarkan oleh bengkel zul. Indikator pelayanan yang baik diperoleh nilai rata-rata sebesar 3,63 dengan kriteria jawaban puas.

Cara meningkatkannya lebih meningkatkan lagi dalam bersikap ramah kepada pelanggan. Dari hasil evaluasi di atas dapat disimpulkan bahwa masih ada beberapa indikator yang rendah. Bengkel $\mathrm{Zul}$ Keluarga Jaya perlu memperbaiki kekurangankekurangan yang ada agar Bengkel Zul Keluarga Jaya menjadi tempat yang banyak konsumennya.

\section{KESIMPULAN DAN SARAN}

\section{Kesimpulan}

Adapun kesimpulan-kesimpulan yang dapat diberikan oleh penulis dari penelitian yang telah dilakukan adalah sebagai berikut:

1. Hasil analisis deskriptif kualitatif tentang harga di Bengkel Zul Keluarga Jaya memiliki nilai rata-rata 3,95 dengan kriteria jawaban baik. Untuk nilai tertinggi 4,23 pada dimensi cara pembayaran untuk indikator kemudahan pembayaran. Untuk nilai terendah dengan nilai rata-rata 3,23 pada dimensi keterjangkauan harga dengan indikator penentuan harga serta dimensi potongan harga untuk indikator penghargaan yang diberikan dengan nilai ratarata 3,30.

2. Hasil analisis deskriptif kualitatif tentang kualitas pelayanan di Bengkel Zul Keluarga Jaya memiliki nilai rata-rata 3,74 . Untuk nilai tertinggi dapat dilihat pada dimensi kehandalan dengan indikator pemberian kesan yang baik dengan memiliki nilai rata-rata 4,03. Sedangkan untuk nilai terendah terdapat pada dimensi bukti fisik dengan indikator memiliki pengetahuan yang cukup tentang produk memiliki nilai rata-rata 3,23 .

3. Hasil analisis deskriptif kualitatif tentang kepuasan pelanggan di Bengkel Zul Keluarga Jaya memilki nilai rata-rata 3,75 . Untuk nilai tertinggi 4,13 pada dimaensi emosi dengan indikator tingkat kepuasan. Nilai terendah dengan nilai rata-rata 3,23 , pada dimensi kualitas produk dengan indikator daya tahan produk.

4. Hasil analisis regresi diperoleh persamaan $\hat{\mathrm{Y}}=$ $3,629+0,386 \mathrm{X}_{1}+0,299 \mathrm{X}_{2}$, artinya terdapat pengaruh yang positif antara harga dan kualitas pelayanan terhadap kepuasan pelanggan di Bengkel Zul Keluarga Jaya.

5. Hasil nilai korelasi diperoleh nilai $\mathrm{r}=0,683$, yang artinya terdapat hubungan yang kuat dan positif antara harga, kualitas pelayanan dan kepuasan pelanggan di Bengkel Zul Keluarga Jaya. Kemudian diperoleh nilai koefisien determinasi R Square $=0,466$, artinya tinggi rendahnya kepuasan pelanggan di Bengkel Zul Keluarga Jaya sebesar 68,3\% dapat dijelaskan oleh harga dan kualitas pelayanan, sedangkan sisanya $31,7 \%$ dipengaruhi oleh faktor lain yaitu, citra merek, pelayanan, harga, promosi dan lain-lain.

6. Hasil pengujian $\mathrm{F}_{\text {hitung }}$ sebesar 11,802 sedangkan $\mathrm{F}_{\text {tabel }}$ dengan $(0,05 ; 2$ vs 30$)(30-2-1=27)$ sebesar 3,35 atau dengan signifikan $0,000<\alpha$ 0,05 , maka $\mathrm{H}_{0}$ ditolak, artinya harga dan kualitas pelayanan berpengaruh positif dan signifikan terhadap kepuasan pelanggan di Bengkel Zul Keluarga Jaya.

7. Hasil pengujian $t_{\text {hitung }}$ pada variabel $\mathrm{X}_{1}$ (harga) sebesar 2,267 $>$ dari tabel dengan $\mathrm{df}=\mathrm{n}-\mathrm{k}-1(30-$ $2-1=27)$ sebesar 2,05183 atau taraf signifikan $0,032<\alpha 0,05$ maka $\mathrm{H}_{0}$ ditolak, artinya harga berpengaruh positif dan signifikan terhadap kepuasan pelanggan di Bengkel Zul Keluarga Jaya. Kemudian nilai $t_{\text {hitung }}$ pada variabel $\mathrm{X}_{2}$ (kualitas pelayanan) sebesar 3,078 $>$ dari $\mathrm{t}_{\text {tabel }}$ dengan $\mathrm{df}=\mathrm{n}-\mathrm{k}-1,(30-2-1=27)$ sebesar 2,05183 atau taraf signifikan $0,005<\alpha 0,05$, maka $\mathrm{H}_{0}$ ditolak, artinya kualitas pelayanan berpengaruh positif dan signifikan terhadap kepuasan pelanggan di Bengkel Zul Keluarga Jaya.

2. Saran 
Berdasarkan evaluasi pada bab sebelumnya maka perlu dikemukakan beberapa saran yang dapat berguna bagi pihak terkait untuk mengatasi kelemahan-kelemahan yang terjadi, yaitu sebagai berikut:

1. Untuk mengefektifkan strategi harga di Bengkel Zul Keluarga Jaya. Teknik harus membuat program lain yang dapat menambah atau mengurangi potongan harga yang diberikan kepada konsumen. Besarnya potongan dapat mengurangi harga yang tinggi pada Bengkel Zul Keluarga Jaya.

2. Kualitas pelayanan pada Bengkel Zul Keluarga Jaya sudah baik. Untuk meningkatkan dan memperbaikinya sebaiknya Bengkel Zul Keluarga Jaya melatih karyawan untuk pelayanan lebih baik lagi dalam melayani pelanggan, dan memberikan pelatihan kepada karyawan agar memiliki pengetahuan lebih banyak lagi tentang produk.

3. Kepuasan pelanggan di Bengkel Zul Keluarga Jaya sudah baik, tetapi masih terdapat beberapa indikator yang rendah. Untuk meningkatkan dan memperbaikinya sebaiknya Bengkel Zul Keluarga Jaya memberikan hasil kinerja yang baik terhadap pelanggan, memberikan informasi yang jelas terhadap produk yang ditawarkan dan lebih meningkatkan lagi kualitas terhadap produk dan jasa yang ditawarkan kepada pelanggan.

Sehubungan dengan keterbatasan pada penulis, penelitian ini masih banyak terdapat kelemahan dan belum dapat mengungkapkan seluruh variabel yang dapat mempengaruhi kepuasan pelanggan di Bengkel Zul Keluarga Jaya. Sebagai bahan penelitian selanjutnya, perlu memperbanyak variabel seperti citra merek, pelayanan, harga, promosi dan lain-lain yang tidak dibahas dalam penelitian ini.

\section{DAFTAR PUSTAKA}

Alma, Buchari. 2007. Manajemen Pemasaran dan Pemasaran Jasa. Bandung: CV Alfabeta.

Daft, Richard L. 2007. Manajemen,Edisi Keenam. Jakarta: Salemba Empat.

Gerson, Richard F. 2002. Mengukur Kepuasan

Pelanggan. Jilid Kedua. Jakarta: Penerbit PPM.

Handoko, T. Hani. 2009. Manajemen, Edisi Kedua. Yogyakarta: BPFE.

Jasfar, Farida .2005. Manajemen Jasa. Jakarta: Penerbit Ghalia Indonesia.

Juwandi, Hendy Irawan. 2004. Kepuasan Pelayanan Jasa. Jakarta: penerbit Erlangga.

Kotler, 2003. Manajemen Pemasaran, jilid 1. Jakarta: Penerbit PT. Indeks.

Krismono, Gugup. 2001. Pengantar Bisnis. Edisi Pertama, Yogyakarta: BPFE.

Lupiyoadi \& A. Hamdani, 2006. Manajemen Pemasaran Jasa. Edisi 2. Jakarta: Penerbit Salemba Empat.
Lovelock dan Laurance Wright. 2007. Manajemen Pemasaran Jasa. Edisi kedua, Jakarta: PT. Indeks.

Nasution, M. Nur. 2004. Manajemen Jasa Terpadu. Bogor: Penerbit Ghalia Indonesia.

Robbins, Stephen P \& Mary Coutler. 2005. Manajemen. Jakarta: PT. Indeks Kelompok Gramedia.

Saladin, Djasalim. 2002. ManajemenPemasaran. Yogyakarta: GrahaIlmu.

Simbolon, Hotman. 2009. Statistika Yogyakarta: Penerbit Graha Ilmu.

Sugiyono. 2012. Metode Penelitian Kuantitatif Kualitatif dan R\&D. Bandung: Alfabeta.

Swasttha, Basu dan Irawan. 2002. Manajemen

Pemasaran Modern. Yogyakarta: Liberty.

Terry, George R \& Leslie W Rue. 2010. Dasardasar Manajemen, Cetakan 11. Jakarta: PT Bumi Aksara.

Tjiptono, Gregorius Candra. 2012. Service Management Meningkatkan Layanan Prima. Jakarta: Andi.

Umar, Husein. 2004. Metode Riset Perilaku

Konsumen Jasa. Bogor: Ghalia Indonesia.

Yamit, Zulian. 2010.Manajemen Kualitas Produk \& Jasa. Yogyakarta:Penerbit Ekonesia. 